\title{
EL REINO NAZARÍ DE GRANADA SEGÚN UN VIAJERO MUDÉJAR ALMERIENSE: IBN AȘ-ȘABBĀḤ (M. DESPUÉS 895/1490)
}

Francisco Franco Sánchez ${ }^{1}$

\section{INTRODUCCIÓN}

En el número anterior de esta misma revista presentamos un texto interesante para el conocimiento de los mudéjares que salieron de Al-Andalus y luego tuvieron el valor de volver a sus lugares de origen, aun sabiendo que su vida bajo un gobierno cristiano distaría de ser cómoda, y teniendo conciencia también de que no serían comprendidos por muchos de sus correligionarios ${ }^{2}$.

Ŷumaca Šayja está dando a conocer paulatinamente la riḥla de Ibn Aș-Ṣabbāḥ, conservada en el manuscrito n. ${ }^{\circ} 2.295$ de la Dār Al-Kutub Al-Wațanīya de Túnez, obra titulada Minšăb al-ajbār wa-tad kirat al-ajyār ${ }^{3}$. Su autor, 'Abd Allāh Ibn Aṣ-Ṣabbāḥ, Al-Așbahị̄ Al-Andalusĩ apenas lo conocemos por su propia obra: pertenecía a la tribu de los Qahțānī(es) del sur, y de ella a la cábila de los Șabbāhịi(es) del Yemen; alardeando de este rancio abolengo llega a asegurar que esta cábila participó en la primera conquista de Al-Andalus ${ }^{4}$. Habitó en la ciudad de Almería, residiendo allí hasta después

1. Estudios Árabes e Islámicos, Universidad de Alicante.

2. Francisco FrANCO SÁNCHEZ, «Los mudéjares, según la riḥla de Ibn Aṣ-Șabbāḥ (m. después 895/ 1490)", Sharq al-Andalus. Estudios Mudéjares y Moriscos, n. ${ }^{\circ}$ 12, Teruel-Alicante, Instituto de Estudios Turolenses / Área de Estudios Árabes Universidad de Alicante, 1995, pp. 375-391.

3. Remitimos a nuestro estudio precitado para las características del manuscrito, así como la bibliografía sobre este autor. Mención especial merece el trabajo de Ŷumaca ŠAYJA, «Bacd al-mazāhir ad-dīnīya fĩ rihlat cAbd Allāh Ibn Aș-Șabbāḥ Al-Andalusī», Dirāsāt Andalusĩyă n. 12 , Túnez, 1994 Juin/1415 Muharram, pp. 36-44, en el que dio a conocer por extenso su figura y personalidad.

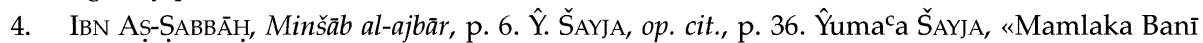
1-Ahmar min jilāl "Minšăb al-ajbār wa-tadkirat al-ajyār" li-c'Abd Allāh Ibn Aṣ-Ṣabbāḥ Al-Aṣbahī», Sharq al-Andalus. Estudios Árabes. Homenaje a María Jesús Rubiera Mata, n. ${ }^{\circ}$ 10-11, Älicante, 1993-1994, pp. 291-305 (pp. 1-2). 
de ser tomada por Fernando, rey de Castilla, en 895/1490. Afirma que memorizó el Corán durante una estancia en La Meca que duró un año completo, siendo por ello un hăfiz; a lo largo de su peregrinación también aprovechó su estancia en las ciudades más importantes para aprender con los ulemas de su época. Pero sus conocimientos parecen ser desiguales, según las materias: a partir de su rihla se deduce que poseía mediana cultura religiosa y notable de historia, pero utiliza una lengua y un estilo poco cuidados; hay que puntualizar que la obra fue dictada oralmente a un -hasta ahora- desconocido transcriptor ${ }^{5}$.

El Minšāb al-ajbār wa-tadkirat al-ajyār es una rihlla hị̂̄āzīya, o relación de su peregrinación a los Santos Lugares del Islam, obra en la que también hay grandes dosis autobiográficas. En ella hallamos multitud de perfiles de análisis sobre la sociedad andalusí y mudéjar almeriense, junto a informaciones diversas sobre las localidades y países por los que pasó.

Ibn Aṣ-Ṣabbāh dictó su relación de viaje tras la conquista de Almería por los castellanos del rey Fernando, es decir después de 895/1490. Dice dictarla de memoria entre los 60 y los 70 años, por tener ya la vista deteriorada ${ }^{6}$. Como no se apunta fecha alguna para la realización del viaje, el Prof. Ŷ. Šayja se remite a los nombres de los sultanes turcos que menciona, como Murad II (que gobierna entre 824-855/1421-1451), y a los ulemas citados, como Badr Ad-Dīn Al-Balqīnī Al-Mișrī (m. 890/1485). Se apunta finalmente la data de la década de 1450 y el principio de la de los años 60, realizando la peregrinación cuando tenía entre 20 y 30 años

En espera de la edición del texto íntegro de la relación del viaje de Ibn Aș-Ṣabbāh, Ŷ. Šayja ya ha adelantado fragmentos de la obra. Entre éstos contamos con algunos párrafos espigados de la misma. En ellos se puede atisbar el panorama que este mudéjar nos quiere presentar de un Reino de Granada que no pervive sino en su memoria ${ }^{8}$. De esta visión nos vamos a ocupar seguidamente.

\section{El ReINO DE GRANADA EN LA OBRA DE IBN Aș-ṢABbĀḤ}

Entre los fragmentos que han sido publicados de esta obra, nos llamaron la atención aquellos párrafos que dedica al Reino de Granada. Fueron entresacados de la obra y reunidos por $\hat{Y}$. Šayja y vieron la luz en el número

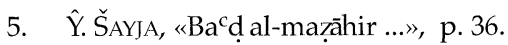

6. IBN Aș-ṢABBAH, op. cit., p. 544.

7. Ibidem, p. 207 r. Y. Š ŠYJA, op. cit., p. 37.

8. ŶYumaca ŠAYJA, «Mamlaka Banī l-Ahmar...», pp. 291-305. 
de esta revista que se dedicó como Homenaje a María Jesús Rubiera Mata ${ }^{9}$. Hay que puntualizar, por tanto, que son fragmentos dispersos; no se trata de una larga descripción o capítulo (como el que le dedica, por ejemplo, Ibn Batṭitāā) sino apuntes más o menos largos en que se habla del reino nașrī y/o de AlAndalus. Dos párrafos breves sobre el Reino de Granada fueron ya publicados al final del anterior artículo que dedicamos a Ibn Aṣ-Sabbāh, y nos sirvieron para adelantar unas primeras conclusiones.

Presentamos seguidamente la traducción de los textos sobre el "reino de los Banū l-Aḥmar" que se encuentran en la riḥla de Ibn Aṣ-Ṣabbāh, según han sido seleccionados y publicados por $\hat{Y}$. Šayja. Se ha separado en puntos aparte para una mejor comprensión de los grupos temáticos o de sentido, y se respeta -en lo posible- la puntuación del editor.

\section{TRADUCCIÓN DE LOS TEXTOS ÁRABES}

\section{$\S 1$.}

«Llegué a la ciudad de Granada, que es la morada de su realeza. Es una ciudad de bellas construcciones públicas y hermosos rincones, que pende de la montaña; / (17v) sobre ella se encuentra la Alhambra, que es la residencia del sultán. Es una ciudad generosa. En ella hay de toda clase de bienes: abundan las aguas, los sembrados, los cultivos, las huertas, las verduras y tiene muchas edificaciones; todo ello prolifera en ciudades y fortalezas. Es una capital de su reino y entre sus gentes: hay rectitud en la administración de justicia; corrección en las ventas y las compras; respetan lo recomendado y rehúsan lo reprobado. No hay ${ }^{10}$ en ella nadie hambriento, ni desnudo, ni quien proteste, ni quien llore, y esto indica que reina la justicia y la benevolencia. En sus gentes reside la bondad y la piedad ${ }^{11}$.

De mi tristeza por la pérdida de la península de Al-Andalus me consuela -y doy gracias a Dios-, porque dejó una parte de la península de España (ŷazīrat Isbãnīya) bajo el gobierno de los musulmanes ;Gracias a Dios! / (18r) Doy gracias a Dios cuando le irrita alguna de sus criaturas, ya que su clemencia, su generosidad, su liberalidad, su gracia y su misericordia, vencen a su indignación y su cólera.

9. Ibídem.

10. En este caso, para la negación, se utiliza la partícula negativa lã (que requeriría un verbo) en vez de laysa para la negación de la existencia de algo.

11. Indica en nota el editor que en el original consta "iṣlăh" "beneficencia, bondad; reparación, corrección", pero no justifica por qué restituye el texto como "ṣalāh" "bondad, piedad, devoción". 
Dice Ibn Aș-Sabbāh: Cuando vi los dominios ${ }^{12}$ de Ibn Al-Ahmar, afirmé: "Alabado seas, Señor de los inicios, Señor de todas las cosas. Tú eres el Dios único, no hay otro dios sino Tú", y recordé la historia de nuestro padre Adán, su salida y caída del Paraíso» ${ }^{13}$.

\section{$\S 2$.}

«Dice Ibn Aș-Ṣabbāh: entré en el país, y conviví con los devotos de Dios. No vi otro mejor, ni más excelente que el territorio de Al-Andalus: quien vive en él es un bienaventurado, quien muere en él es un mártir. Ello demuestra que aquella tierra es lo último que les resta a los devotos. Sus pobladores son los últimos devotos» ${ }^{14}$.

\section{$\S 3$.}

«Dice el autor-Dios se apiade de él-: No quedan reyes de los tabābic $a^{15}$-que eran reyes qahtānies ${ }^{16}$, ni himyaries ${ }^{17}$, sino estos descendientes de la monarquía de Al-Andalus» ${ }^{1 \dot{8}}$.

\section{$\S 4$.}

«Dice el autor: Entré en la ciudad de Granada -iDios la devuelva al Islam y triunfe en ella!-, y vi en ella bellos edificios privados, buenas construcciones públicas y ríos surcándola por medio de ella. También vi a ulemas, lectores coránicos, y a los siete jueces, cuyos nombres eran renombrados entre los viajeros.

12. Para referirse el Reino de Granada (y más adelante a Siria y Egipto) sólo dos veces utiliza el término "mamlaka", "reino". Por lo común, lo califica de "milk Ibn Al-Ahmar", o sea "propiedad, posesiones, patrimonio, dominio, estatal de Ibn Al-Ahmar". P. de Alcalá lo interpreta "eredad, milk" (apud Reinhardt P. Dozy, Supplément aux Dictionnaires Arabes, Leiden-París, ed. E.J. Brill / G.P. Maisonneuve et Larose, 1881, vol. II, p. 622). Lo traduciremos por "reino" cuando convenga al sentido, indicando adjunto el término árabe en todo caso.

13. Añade el editor a renglón seguido del texto original, y entre paréntesis, una breve glosa del texto que sigue: "Prosigue el autor comparando la salida de Adán del paraíso y la salida de las gentes de Al-Andalus de su país". IBN AȘ-ṢABBAH, op. cit., pp. 17 r, 17 v, 18 r. Y̌. ŠAYJA: «Mamlaka Banī l-Aḥmar...», pp. 297-298.

14. Entre paréntesis, indica el editor que prosigue el texto de la obra (texto que no copia). IBN Aș-ṢABBAH, op. cit., p. 21 v. Ŷ. ŠAYJA, «Mamlaka Banī l-Ahmar ...», p. 298.

15. Se refiere a la monarquía sudarábiga preislámica, que hunde sus orígenes en la historia mítica.

16. Descendientes de Qahțān, antepasado mítico de los árabes yemeníes o del sur.

17. Descendientes de Himyar, hijo de la reina de Saba, y raza de los habitantes primitivos del Yemen. Tribu árabe del sur de la península Arábiga.

18. Nuevamente, indica el editor que el texto continúa (es de suponer que con temática diferente). IBN Aṣ-ṢABBAH, op. cit., p. 23 r. Ŷ. ŠAYJA, «Mamlaka Banī l-Aḥmar ...», p. 298. 
Es una ciudad que pende de un monte - de Sierra Nevada (Ŷabal Sulayr, sic)-; con un aspecto extraordinario, mira hacia el territorio enemigo; de blancas murallas, es una bella ciudad, con una corona encima de su cabeza ${ }^{19}$ : es la residencia del sultán titulado "de la Alhambra", / (30v) que derrama desde ella agua y verdor. Es una ciudad adornada con muchos árboles, edificios privados y alcázares (qușūr). Entre todo lo que encierra, en ella hay un millón de jardines, hay un millón de alcázares habitados por hombres, niños y mujeres. En tiempo de los frutos está llena de buena gente. En cada alcázar (qașr) se encuentra el canto y la música durante cinco meses, con comida, bebida, fiesta y alegría ${ }^{20}$.

La ciudad de Granada no tiene semejante entre todas las ciudades de Al-Andalus. Es ciudad en la que hay rectitud en toda la administación de justicia: en el almotacenazgo, en los precios, en las ventas y en las compras, tomando precauciones contra la usura, y observando lo lícito.

La ciudad / (31r) de Granada tiene buena atmósfera y buenas aguas; se ven elegantes brocados ${ }^{21}$ en hombres, niños y mujeres y son frecuentes los ricos trajes $y$ los vestidos. Hay extensos sembrados, mucho ganado ${ }^{22}$, excelentes dehesas (almarcà), y mucha esperanza en todos los asuntos. Quien la habita es bienaventurado, y quien es muerto en ella es un mártir.

Es suficiente con que el enemigo la observe, para que sea sometido; suficiente es que ella combata con Satanás y con los seguidores de los ídolos para ser vencedora de los señores de las cruces, los cristianos. La ve el enemigo y se angustia. Basta con los símbolos de la opulencia del Islam que en ella han perdurado contra los adoradores de los ídolos y las cruces. Tiene ciudades y fortalezas de renombre. Hay caballería regular ${ }^{23}$ en las fronteras de los cristianos; están preparados con gran número de tropas y material de guerra, / (31v) con las espadas afiladas; están dispuestos a toda hora y en cualquier época; esperan al enemigo con los pechos distendidos y los corazones alegres. Sus algazúas son renombradas, sus estandartes difundidos y sus contraataques victoriosos. Sometieron al enemigo e hicieron triunifar la religión. Están orgullosas de ellos las capitales de los musulmanes» ${ }^{24}$.

19. La Alhambra como corona real y metafórica de Granada: lugar donde se asienta el poder; a su vez, la Alhambra circunda cual corona el monte a cuyo pie se extiende la ciudad.

20. En el original dice: "comida, música, fiesta y alegría (al-akl wa-ț-țarab wa-l-farah wa-s-surūr)" (n. 53), mientras que el editor, suponemos que por el sentido -aunque no lo justifica-restituye: "comida, bebida, fiesta y alegría (wa-š-šurb wa-l-farah wa-s-surūr)".

21. Interpreto "dībāh" como "dī bā $\hat{y}$ brocado, tela de seda", acorde con el sentido de la frase y con la nota explicativa del editor n. ${ }^{\circ} 55$.

22. "An-nasl". Según P. de Alcalá es "generacion como linage, genero por linage noble", "generacion venidera" (apud. R.P. DozY, op. cit., vol. II, p. 676: "alto linaje"). Pero, como el término se incluye entre las riquezas de las ciudades, pensamos que se refiere a "ganado, animal reproductor (nusüla)" y por esta interpretación nos hemos inclinado.

23. "Wa-l-juyūl al-murattaba fịtugūr ar-rūm": fuerzas de caballería regular, organizada, acantonada en las fronteras frente a los cristianos.

24. IBN Aṣ-ṢABBẠ, op. cit., pp. 30 r, 30 v, 31 r, 31 v. Ŷ. ŠAYJA, «Mamlaka Banī l-Aḥmar ...», pp. 298300. 


\section{$\S 5$.}

«Dice el autor-Dios le bendiga-: quien quiera ver / (32r) a Damasco -del Šām-, que mire hacia Valencia y a Granada, y lo verá en sus aguas, sus aires, sus edificios privados y sus buenas construcciones públicas. Mi alma no se alivia cuando entro en las ciudades en que tomo residencia, si no es en la ciudad de Granada. Hay en ella muchas fortalezas, alquerías y ciudades, como en Siria. Han sido los viajeros que describieron las ciudades, quienes dijeron: "La península de Al-Andalus es sublime". Y es cierta esta afirmación suya ${ }^{25}$.

Afirma el autor: De los siete climas existentes, de los cinco por los que viajé26 no vi mejor, ni con más donaire, ni más luminoso panorama como en la tierra de Valencia, la tierra de Murcia, la tierra de Córdoba, y la tierra de Granada. Quien quiera ver / (32v) Siria ${ }^{27}$ que mire a este país de Al-Andalus -aunque Siria sea tierra sagrada ${ }^{28}$, en ella está el lugar de reunión, y en ella está el destino-.

El país de los Banū l-Ahmar ${ }^{29}$ tiene ciudades en número comparable con Siria: como Málaga, Guadix, Baza (Bașta, sic) -la casa del azafrán-, Almería -la morada de los comerciantes-, Almuñécar (Munakab, sic) -la sede de la caña dulce y del azúcar-, Málaga -la casa de la loza dorada-30, Sierra Nevada -la morada de la seda temprana-31. Debajo de ésta, la ya citada ciudad de Granada / (33r) es la sede de la artesanía del tejido de la tela de seda ${ }^{32}$ y del tafetán ${ }^{33}$. No se ve en el país otra manufactura; es todo lo que produce su población en cuanto a artesanías. Esto semeja lo que hay en la ciudad de Granada y su reino, además de sus sembrados y su ganado.

Se satisface con el excedente del terreno y de las regiones. Es un país en que no se interrumpe la producción de cosechas en el campo, ni de frutos, en el que sus cereales son abundantes, $y$ sus viviendas son amplias ${ }^{34}$. No hay entre ellos temor en

25. Lit.: "Y es esta verdad lo que dijeron".

26. Lit.: "No vi en los cinco climas (aqālīm) en que entré, de los siete climas (aqālīm), ...".

27. Lit.: "el reino (milk) de $\check{S} \bar{a} m$ ".

28. "Al-ardal-muqaddasa": "la tierra sagrada", si acaso, para cristianos y judíos (pues podría incluirse Jerusalén en esta región), pero en un tercer lugar para los musulmanes (tras La Meca y Medina).

29. Lit.: "La heredad/patrimonio de los Banū l-Ahmar". Emplea una perífrasis para no utilizar el término "mamlaka", reino constituido, mientras que pone énfasis en el dominio familiar y señorial sobre el territorio de Granada.

30. Lit.: "wa-Mālaqa, dār ad-dahab fil-fajjār".

31. Lit.: "Wa-ŷabal Šulayr, dār al-harīr al-miftahān" (sic): Sierra Nevada, la casa de la seda temprana. El último término no lo hallamos en los diccionarios.

32. "Al-ḥarīr aš-šarb": "una especie de seda", R.P. DozY, op. cit., vol. I, p. 740.

33. Siguendo a R.P. Dozy (op. cit., vol. I, p. 585), en vez de "wa-z-zardahān" interpreto "wa-z-zardajāna": "tipo de seda fina que se parece al tafetán".

34. Enmienda del editor, según lo pide el sentido. En la nota 80 indica que el original dice " $y$ sus edificios (civiles) son abundantes". 
los comercios (mahall); sin haber carestía ${ }^{35}$, los hombres en sus vientres tienen hambre, sus caras son luminosas, sus cuerpos recios, y son sus corazones fieles ${ }^{36}$ en la fe. No prestan oídos ni a lo falso, ni a lo imposible. Los hemos descrito con un carácter como el de los anșār ${ }^{37}$ : son jóvenes libres, combatientes ${ }^{38}$. No ven en Dios sino a un censor severo que reprocha, y no atemorizan sino a los infieles. La muerte en el ŷihäd es para ellos más dulce que la miel, y más tierna que la mantequilla; reclaman la otra vida, y complacen al Señor / (33v) con el esfuerzo, la resolución, la determinación, la energía y el amor. Piden el favor del Clemente, el paraíso de la satisfacción, las huríes de negros ojos y el paraíso de la satisfacción (sic).

Se asemeja el dominio de los Banū l-Ahmar a Siria. En cada alquería hay mezquita con predicación (juṭba), agua, y llamada a la oración, es decir, hay alminares, o sea minaretes ${ }^{39}$; en cada alquería hay un minarete que se asemeja a las torres de la costa; en cada alquería hay jutba (sic). Alquerías y fortalezas semejan en número a las estrellas del cielo, y también a las montañas de Jerusalén. ;Por Dios, su heredad es bendita!, es el resto de la bendición (baraka) que existió en la península de España (ŷazirat Ișbānīya, sic); la prueba de esta bendición se encuentra en el texto coránico y en la victoria sobre el enemigo en todos los años pasados y venideros. Observa / (34r) si no, las numerosas batallas de nuesta época, y de época de nuestros abuelos, jen cuántas batallas vencimos a los enemigos! Basta con mencionar la batalla del desfiladero (waq'a faŷŷ), lo mejor de este tiempo nuestro. Esta es la mejor prueba y el mérito que la destaca ${ }^{40}$ sobre los demás países. Así ocurrió en ella con una numerosa partida de cristianos y un pequeño grupo de musulmanes, como en la batalla de Guadix ${ }^{41}$-que es una capital del reino, con fertilidad, prosperidad y riquezas; en su tierra cuenta con abundancia de aguas, huertas y jardines; entre unos montes, hacia el occidente, está la ciudad de Ronda, en su alfoz tiene muchos cultivos, sembrados y ganado-.

Dice el autor: Después de Siria y Egipto ${ }^{42}$ no hay en los países árabes mejor lugar para el creyente, señalado por lo religioso y lo material, sino la heredad de los

35. Restituye el editor: "sin haber carestía (wa lā $\hat{y} \bar{u}$ c)", indicando que en el original consta "y no hay reclamación (wa lā ruŷūc)" (nota 82 ).

36. Corrección del editor: " $y$ son sus corazones fieles [en la fe] (wa-qulūbu-hum mu'mina)", en vez del original " $y$ [tienen] sus corazones convicción (wa-qulūbu-hum caqĩda)" (nota 83).

37. Los "auxiliares" medineses que ayudaron a Mahoma. En el original, con escaso respeto a la sintaxis árabe, dice: "Los hemos descrito [como se] describe a los anșär" (notas 84 a 86).

38. Según Pedro de Alcalá: "corredor del campo" (apud R.P. DozY, op. cit., vol. II, p. 230: "quien hace incursiones"), es decir "almogávares".

39. Lit.: "es decir, hay alminares (bi-1-mādin), [o sea] minaretes (șawāmic)"; el segundo término de la aclaración es más propio de Al-Andalus y el Mágreb.

40. Añadido del editor, según el contexto.

41. Sobre la "Waq'a Wādī Āš", "batalla de Guadix", vide infra.

42. Los cita como "el reino de Siria (milk Aš-Šām) y el reino de Egipto (milk Miṣr)". 
Banū l-Ahmar, en Al-Andalus. Con la ayuda de Dios ${ }^{43}, /$ (34v) esto es lo que hemos resumido de las historias de la península de España ${ }^{44}$, y de lo que en ella ocurrió de bueno y de malo. Pedimos a Dios nuestro Señor que sea bondadoso con la descendencia que permanece, y que extienda un velo protector sobre los fieles a la religión que están bajo la dimma en la citada península ${ }^{45}$; que no castigue a quien tuvo la posibilidad de salir de ella, y no salió. Que Dios no les sancione con el castigo; ciertamente, Él es liberal, generoso, indulgente, no se precipita (sic), y les salva con la bendición de la profesión islámica de fe en el 'monoteísmo'46 y con la 'intención' (niyya) sincera en la religión de Dios y en la ley canónica (šarīa) de Su Profeta -isobre él sea la paz!- ${ }^{47}$. Pedimos a Dios nuestro Señor que reúna a la comunidad (ŷamāca) de los musulmanes en los jardines del Paraíso, con los profetas, / (35r) los mártires y los devotos ${ }^{48}$. Amén. ;Oh, Señor del universo! Dios, el Altísimo, dice:

"Asignamos esa Morada Postrera a quienes no quieren conducirse con altivez en la tierra, ni corromper. El buen final es para los que temen a Alläh" ${ }^{49}$.

\section{$\S 6$.}

«Sali del país de Al-Andalus, y ha sido descrito en sus bondades y diferencias $^{50}$. iDios es quien da el éxito principal!

Nos fuimos del dominio de los Banū l-Ahmar. Éste se extiende por una distancia de siete jornadas a lo largo, $y$ tres a lo ancho, sin embargo, se halla bien poblado de alquerías y fortalezas. Todas sus poblaciones se hallan enfrente una de otra; no está alejada una ciudad de otra, una alquería de su vecina, una fortaleza de la otra. Todas ellas miran / (38v) una a la otra inmediata. ;Dios restaure el Islam hasta el día de la Resurrección!» 51 .

43. Nueva incorrección sintáctica: "Wa-bi-llah at-tawfrq" en vez de "Wa-bi-t-tawfiq min Allāh".

44. Lit: "mā ijtiṣar-nā frqișsa ŷazirat Iṣbānīya" (sic).

45. Lit.: "Calà al-mu'minīn ad-dìn tahta d-dimma fill-ŷazìrat al-madkūra".

46. Lit.: "yunâŷŷ-him bi-barakat kalimat at-tawhīd", es decir con la bendición de la creencia en la unicidad de Allāh. La palabra "unificación" o "monoteísmo" -el tawhid- es "Allāh", Dios único (frente a su interpretación de la Trinidad cristiana).

47. Lit.: "Wa-niyyat al-ijlāṣ fidìn Allāh wa-šarīca Nabī-hi calay-hi s-salām".

48. Lit.: "Fī ŷannat an-nac ìm maca n-nabī'yĩn wa-š-šuhadā' wa-ṣ-șālihịn" (sic).

49. Corán, 28: 83, sigo la edición bilingüe de Julio CoRTÉs, El Corán, Elmhurst (Nueva York), ed. Tahrike Tarsile Qur'an Inc., $1992^{3}$, p. 382. Al final de este fragmento en árabe, $\hat{Y}$. Šayja indica de nuevo -entre paréntesis- que prosigue el texto de la obra (texto que tampoco copia, ni indica temática). IBN Aș-ṢABBÄ, op. cit., pp. 32 r, 32 v, 33 r, 33 v, 34 r, 34 v, 35 r. Ŷ. ŠAYJA, «Mamlaka Banī l-Aḥmar ...», pp. 300-304.

50. Sic. que también indica el editor. Construcción gramatical extraña, que se inicia en primera persona y continúa en tercera. Por otro lado, en las construcciones de este párrafo hay un uso general de la partícula ${ }^{c} a n$ por min.

51. IBN Aṣ-ṢABBBẠ, op. cit., pp. 38 r, 38 v. Ŷ. ŠAYJA, «Mamlaka Banī l-Ahmmar ...», pp. 304-305. 


\section{DATOS QUE APORTAN ESTOS TEXTOS}

Como son grandes las incógnitas que plantea esta obra recogimos prudentemente sólo algunas conclusiones en nuestro estudio anterior sobre Ibn Aṣ-Ṣabbāh. A la vista de los seis fragmentos de la misma que hemos traducido, se plantean bastantes interrogantes nuevos, a la par que se pueden adelantar algunas conclusiones más. Las exponemos sin ánimo de exhaustividad, a la espera de poder contar con el texto definitivo de la obra (que el prof. Ŷ. Šayja nos comunicó verbalmente que prepara).

Sobre el aspecto formal de los textos, en total son seis fragmentos en los que se trata del Reino de Granada en general, y de Al-Andalus, en ocasiones. De ellos, los epígrafes $1 .^{\circ}$ (ff. $17 \mathrm{r}-18 \mathrm{r}$ ), $2 .^{\circ}$ (f. $21 \mathrm{v}$ ) y $3 .^{\circ}$ (f. 23r) son relativamente cortos (el 2..$^{\circ}$ y el 3. ${ }^{\circ}$ especialmente), y no consecutivos. En los tres el editor afirma que prosigue el texto, aunque sólo en el $10^{\circ}$ precisa el tema: glosando la comparación entre la expulsión de Adán del Paraíso y de los musulmanes de Al-Andalus; en los otros dos no especifica la temática del texto consecutivo. Los fragmentos $4 .^{\circ}$ (ff. 30r-31v) y $5 .^{\circ}$ (ff. 32r-35r) son prácticamente consecutivos entre sí, pues hay menos de folio y medio entre ellos. El $6 .^{\circ}$ (ff. 38r$38 v$ ) y último es breve también, e incluye una cita coránica entre su texto. Sobre el tamaño de cada folio podemos aventurar que es reducido, por el poco texto árabe que hay en cada página. No sabemos la extensión de la obra, pero como cita $\hat{Y}$. Šayja un texto del f. 544, cabe pensar en una obrita de tamaño reducido, pero muy gruesa. Es curioso que en una obra tan amplia sólo se mencione el Reino de Granada en los ff. 17 a 38, al inicio de la misma, y que -según parece- no se vuelva a hablar de él más adelante.

Temáticamente, su fragmentariedad hace que no puedan considerarse como una unidad textual. A pesar de ello, estos textos son redundantes y transmiten unas ideas convergentes: el 1..': es una descripción elogiosa del Reino de Granada y lamento por su pérdida; $2 .^{\circ}$ : elogio de sus habitantes; $3 .^{\circ}$ : apología de su monarquía; $4 .^{\circ}$ : alabanza de la moral de sus habitantes, su economía, y su preparación frente al enemigo cristiano; $5{ }^{\circ}$ : comparación elogiosa con Siria, descripción elogiosa de ciudades y producciones, justificación a los mudéjares; $6 .^{\circ}$ : partida, dimensiones de Al-Andalus y anhelo de su vuelta al Islam.

\section{DATOS LINGÜÍSTICOS}

Como no deja de resaltar $\hat{Y}$. Šayja, estos textos presentan una lengua de escasa calidad literaria, y están tan trufados de incorrecciones o dialectalismos, que ha sido necesaria una amplia labor de restitución por parte del editor; labor que se justifica cara a una correcta comprensión e interpretación del texto. Estas enmiendas y correcciones han sido puntualmente señaladas 
entre paréntesis por el editor y anotadas a pie de página en sus formas diferenciales.

No disponemos de todo el texto. Es ocioso, por tanto, sacar conclusiones lingüísticas globales o absolutas. Por ello, señalamos algunas peculiaridades que se repiten insistentemente, dejando para otro lugar, o para el propio editor árabe, esta tarea lingüística. No señalamos ejemplos, sino los errores, remitiendo a las notas del texto árabe para comprobar estas peculiaridades lingüísticas:

- Gramaticalmente es un texto difícil; aunque en apariencia sencillo, hallamos buen número de incorrecciones sintácticas, que le obligan al editor a añadir partículas que garanticen una coherencia gramatical y un sentido en árabe. Algunas incorrecciones o carencias relevantes las hemos señalado en nuestra traducción. Sintácticamente, las frases suelen ser breves, enunciativas y llenas de anexiones, como si fuera lenguaje infantil, coloquialmente simple, o insuficientemente aprendido. Las partículas son los elementos sintácticos en que hallamos más errores, por omisión, o uso incorrecto ${ }^{52}$.

- Morfológicamente, en ocasiones, hallamos un uso anómalo e irregular de los plurales, de los colectivos, o de algunos femeninos. Hay muchas irregularidades en cuanto a la ortografía del alif maqșūra (suele escribirlo como alif final) y buena cantidad de faltas en la ortografía de los nombres de acción, de color, plurales fractos y participios ${ }^{53}$.

- Léxicamente aparecen algunos dialectalismos del árabe magrebí, aunque no muchos; algunas de las variantes o de los errores en la ortografía de los nombres de acción podrían tener este origen ${ }^{54}$.

- Finalmente, los verbos de existencia son suplidos por la superposición de elementos, en un esquema que muestra una deficiente comprensión del funcionamiento regular de estos verbos ${ }^{55}$.

El que Ibn Aṣ-Ṣabbāh haya dictado oralmente -como Ibn Bațūta- su vida a un copista, permitiría comprender algunas circunstancias lingüísticas, que pueden ser achacables a su mal árabe, o a la incultura o impericia de su copista (muy lejos de la talla de un Ibn Ŷzayy).

52. Aunque hay más ejemplos, anotamos los ya apuntados en la edición de los textos, así remitimos a las notas n. ${ }^{\text {os }} 23,24,26,30,31,33,34,36,49,50,52,56,57,64,65,72,77,78,84,86$, 91, 94, 95, 97, 100, 104, 106, 108, 110, 112, 115, 117, 118, 120, 121, 122, 124 y 125.

53. Como ya indicó el editor en las notas n. ${ }^{\text {os }} 20,35,40,41,45,46,51,58,61,62,63,67,75,87$, $88,90,93,96,114,116,123$ y 126.

54. Ver las notas a la edición n. ${ }^{\text {os }} 22,29,37,54,69,79$ y 103.

55. En dos ocasiones hay un error en el tiempo del verbo "kāna" (notas n. os 53 y 68), mientras que en otras se sustituye la forma correspondiente de "laysa" por la negación (lä) (en ocasiones + frase nominal), como señaló el editor en las notas n. ${ }^{\text {os }} 28$ y 81 . Otras incorreciones verbales son las señaladas en las notas n. ${ }^{\text {os }} 47,66,76,82$ y 85. 
A la espera de un profundo estudio lingüístico sobre esta obra, se pueden avanzar tres posibles hipótesis acerca de sus incorrecciones lingüísticas: que reproducen el árabe de los mudéjares; o un árabe transcrito por un copista cuya primera lengua no ha sido ésta; o que representa la lengua de una copia moderna posterior (cuya fecha o circunstancias desconocemos), realizada por algún copista magrebí descuidado.

La lengua dista del árabe clásico, especialmente en sus aspectos sintácticos; en ocasiones parece una lengua muy moderna, influida por esquemas de las lenguas occidentales (a lo que contribuye la puntuación del editor árabe y su división en párrafos). Por otro lado, hay dos elementos a resaltar: en primer lugar, ya se ha apuntado la extrañeza que produce el uso de los verbos árabes de existencia, lejanamente árabe; a ello se une una peculiaridad sintáctica más moderna que clásica, se trata del alejamiento del esquema de la frase árabe: verbo+sujeto+circunstanciales; el que buen número de frases se inicie con los circunstanciales, seguidos por los demás elementos, no es sino un reflejo "occidental", que aparece en la lengua árabe muy al fin de la Edad Moderna ${ }^{56}$. Estas dos peculiaridades nos hacen pensar que nos hallamos ante una lengua árabe muy influida por sus convecinas peninsulares.

\section{DATOS CRONOLÓGICOS}

Entre las variadas imprecisiones (o, simplemente, ausencia de datos) hay que apuntar la de una fechación en que podamos ubicar este Reino de Granada descrito. Pocos datos cronológicos poseemos relacionados con Ibn Aș-Ṣabbāḥ; sabemos que su peregrinación la hizo hacia el final de la década de los años 1450 y el principio de la de los años 1460, teniendo entre 20 y 30 años. Con posterioridad a ello, residió en la ciudad de Almería hasta después de ser conquistada en el año 895/1490; afirma dictar su relación de viaje tras convertirse en mudéjares los habitantes de Almería, es decir después de su conquista en 895/1490 por los castellanos del rey Fernando. Dice dictarla de memoria entre los 60 y los 70 años, cuando ya tenía debilitada su vista $^{57}$. Ibn Aș-Ṣabbāh viviría como mudéjar, por tanto, en Almería tras la toma de Granada de $1492^{58}$.

Estos datos nos centran su periplo vital granadino entre el 1460-1492, prosiguiendo luego como mudéjar, posiblemente hasta después de iniciado

56. Cfr. v.gr. las 2. ${ }^{\mathrm{a}},{ }^{\mathrm{a}}{ }^{\mathrm{a}}$ y $4 .^{\mathrm{a}}$ frases con que empieza el f. 30v o la última del $33 \mathrm{r}$ (antes del inicio del nuevo párrafo), por no citar sino unos ejemplos espigados entre otros muchos.

57. IBN Aṣ-Ṣ̂ABBĀH, op. cit., p. 544.

58. Sobre estas cronologías, remitimos a nuestro anterior artículo (pp. 376-378), en que se desarrolla la lógica deductiva que le llevó a Ŷ. Šayja a estas conclusiones. 
el s. XVI ${ }^{59}$. Como en los anteriores textos no hay más coordenadas cronológicas que nos sirvan para precisar momentos concretos, hemos de concluir que nos describe un reino granadino atemporal, caracterizado por la imprecisión cronológica.

Únicamente dos hechos permiten aportar alguna fecha a la narración. Cuando dice que «Basta con [mencionar] la batalla del desfiladero (waq ${ }^{\mathrm{c}}$ a faŷŷ), lo mejor de este tiempo nuestro. Esta es la mejor prueba y el mérito [que la destaca] sobre los demás países. [Así] ocurrió en ella con una numerosa partida de cristianos (rūm) y un pequeño grupo de musulmanes, como en la batalla de Guadix». Esta "batalla de Guadix" a que alude sería la que venció Muhammad VI el 19 de rabíc $^{\mathrm{C}}$ I 763/15 de enero de 1362 en Guadix contra un ejército de Pedro I que había entrado en la vega unos meses antes; según anotó Ibn Jaldūn, los granadinos infligieron "perdidas considerables a los cristianos" 60 . No sabemos de otro encuentro victorioso parejo relacionado con Guadix.

Por contra, no hemos hallado cuál pudiera ser la "batalla del desfiladero (waq a faŷŷ)", ni a qué "faŷyे" (desfiladero, garganta, hoz) se refiere. No es muy aventurado suponer que quizás oyera mal el copista a Ibn Aș-Ṣabbāh un término tan específico andalusí como "fạhs, vega, campo de regadío" 61 , y lo transcribiera como "faŷy", lo cual es fonéticamente posible. En tal caso, Ibn Aș-Ṣabbāh rememora una de las grandes victorias nazaríes sobre los castellanos: la "batalla de la Vega (al-faḥs)" de Granada, encuentro armado celebrado el 26 de junio de 1319. Los infantes don Pedro y don Juan de Castilla lucharon contra el sultán Ismācīl y su ejército y según Ibn Jaldūn "el ejército cristiano fue cortado en grupos, a la vista de Granada"; como consecuencia, perdieron los castellanos a sus gobernantes y a un numeroso ejército ${ }^{62}$.

59. En este período se sucedieron los siguientes soberanos nazaríes: $\mathrm{Sa}^{\mathrm{c}} \mathrm{d}(1453.4-1462) *$ Yūsuf $\mathrm{V}(1462) * \mathrm{Sa}^{\mathrm{c}} \mathrm{d}(1462-1464)$ * Abũ l-Ḥasan ${ }^{\mathrm{C}}$ Alī $(1464-1482 / 1482-1485) *$ Muhammad XII (1482/1486-1492).

60. Ver Rachel ARIÉ, L'Espagne musulmane au temps des Nașrides (1232-1492), París, Éditions E. De Boccard, 1973, pp. 110-111.

61. Sobre la toponimia que ha generado, ver: Míkel de EPALZA, «La dualidad Campello-Fahs en el espacio agrícola de Al-Andalus (Alicante-Castalla-Pedreguer-Madrid)», Sharq al-Andälus. Estudios Árabes, n. ${ }^{\circ}$ 4, Alicante, ed. Universidad de Alicante, 1987, pp. 159-173 o «El binomi àrab-mossàrab "Al-Fahs /El Campello", a Lleida”, Societat d'Onomàstica. Butlletí Interior, n. ${ }^{\circ}$ 35, Barcelona, 1989, p. 32. Ahora bien, sobre la vega de Granada la mejor descripción la aporta Ibn Al-Jațīb en el prólogo a su Ihạta; ver la trad. parcial de los textos de la descripción de Granada en: Francisco Javier SIMONET, Descripción del reino de Granada bajo la dominación de los naseritas, sacada de los autores árabes, y seguida del texto inédito de Mohammed Ebn Aljathib, Madrid, ed. Imprenta Nacional, 1860, $223+32$ pp. Cfr. M. ${ }^{a}$ Carmen JiMÉnEZ MATA, La Granada Islámica. Contribución a su estudio geográfico-político-administrativo a través de la toponimia, Granada, ed. Universidad de Granada / Diputación Provincial, 1990, 330 pp.

62. Ver R. ARIÉ, op. cit., pp. 96-98. 
Los hechos bélicos, de 1319 y de 1362, son dos victorias, dos hitos tan importantes como para perdurar en la memoria de los granadinos más de un siglo después.

\section{DATOS TOPONÍMICOS}

I. Entre los datos toponímicos que cita Ibn Aṣ-Ṣabbāh se pueden establecer algunos grupos. Uno primero sobre las poblaciones que cita: Granada como ciudad y como "milk", "heredad, herencia" de los Banū l-Ahmar; curiosamente se nombra de este modo, en vez de "mamlaka", propiamente "reino", pero no pueden sacarse conclusiones unívocas, pues califica como "milk AšŠām" y "milk Mișrr" cuando habla de Siria y Egipto como países; las dos únicas veces que cita "reino" es para decir que Granada y Guadix son "dār mamlaka", "una capital del reino"63. Menciona además Sierra Nevada (Ŷabal Sulayr/Šulayr), la Alhambra (Al-Hamrā') la tierra (ard) de Valencia, la tierra de Murcia, la tierra de Córdoba, Málaga (Mālaqa), Guadix (Wādī Âš), Baza (Bașta, sic), Almería (Al-Marīya), Almuñécar (Munakab, sic).

Fuera de Al-Andalus alude a: "Damasco del Šām", para compararla con el territorio granadino; esta semejanza se hace en cuanto a territorio muy habitado, densamente poblado ("el país de los Banū l-Ahmar tiene ciudades en número comparable con Siria (milk Aš-Šãm)", "Hay en ella muchas fortalezas, alquerías y ciudades, como en Siria") curioso es también que afirme de Aš-Šãm/Siria que: "aunque Siria (Aš-Šām) sea tierra sagrada, en ella está el lugar de reunión (almaḩ̌̌ar), y en ella está el destino", pues es testimonio más propio de un judío o cristiano que de un musulmán. En estos párrafos también cita Jerusalén, como territorio -suponemos que- muy poblado: "Alquerías y fortalezas semejan [en número] a las estrellas del cielo, y también a las montañas de Jerusalén"64.

II. En segundo lugar, hemos de apuntar que en su texto ya hallamos una conciencia de clara diferencia entre la Península Ibérica o de Al-Andalus y el dominio musulmán o Reino de Granada. Esta identificación rompe la identificación general de la península con el territorio andalusí. A AlAndalus se le califica como "país (bilād) [de Al-Andalus]", "la península de AlAndalus es sublime (sāmìa)", y como "tierra (arḍ)".

63. Siendo erróneo que Guadix fuera capital del reino (lo cual sólo le correspondía a Granada), sí que era su segunda ciudad, refugio de todo sultán destronado y una de las bases militares y de los dominios económicos esenciales de los nazaríes.

64. Comparación tampoco esperable en un musulmán. Ya resaltamos en nuestro anterior estudio sobre Ibn Aș-Ṣabbāḥ (p. 382) que, de modo poco ortodoxo, defiende como auténtico "hây $\hat{y}$ " la peregrinación a Jerusalén, cuando no fuera posible realizarla a La Meca o Medina. Él la había realizado y la considera suficiente para algunos musulmanes débiles en econo-

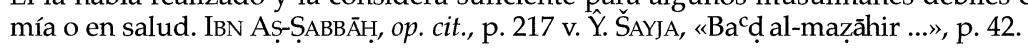


Por otro lado, en dos ocasiones menciona la "península de Al-Andalus (ŷazirat Al-Andalus)" frente a otras tres en que lo hace de la "peninsula de España". En cuanto a ello hay que apuntar dos circunstancias: una primera, de lógica interpretativa del nombre "España" entre los escritores árabes, andalusíes o no. En Al-Andalus y en las obras escritas en árabe, a la Península Ibérica se la conoce como "Ŷazìrat Al-Andalus". Los reinos cristianos se autodenominaban: Reino de Aragón, de Castilla, León, de Valencia, Cataluña, etc. y, a su vez, nombran al territorio andalusí "España" (especialmente en la corona catalano-aragonesa). Causa, por ello, extrañeza que un andalusí, que escribe en Almería en el s. XV hable de "península de España" (Ŷazīrat Iș̣ānīya)" por "península de Al-Andalus". Este uso sería más propio de un castellano o un catalano-aragonés (o un magrebí de época posterior), aunque no aplicado a toda la Península Ibérica, sino sólo al territorio andalusí.

Una segunda circunstancia se refiere a la ortografía del nombre: "ŷazirat Ișbānīya". Este modo de escribir nos habla de un posible origen magrebí de la lengua y formación de su autor, o su copista; así escriben el nombre de "España" unos viajeros marroquíes que vienen a la península algunos siglos después ${ }^{65}$. En idéntico sentido apunta (aunque de modo menos concluyente) su aclaración semántica: "es decir, hay alminares (bi-1-mādin), [o sea] minaretes (șawāmic)", mientras que el primer término es genérico, el segundo es propio de Al-Andalus y el Mágreb.

III. Finalmente, la comparación de Al-Andalus con "Damasco del Šãm" y con Siria en general, es un tópico de la literatura árabe, hasta nuestros días. Recuérdense los abundantes ejemplos en este sentido ${ }^{66}$, arquetipos poéticos utilizados desde ${ }^{\mathrm{C}} \mathrm{Abd}$ Ar-Raḥmān I, pasando por ${ }^{\mathrm{C}} \mathrm{Abd}$ Al-Basīt (vide infra) hasta el mismo Nizar Kabbānī.

IV. El origen de los evidentes errores ortográficos que hallamos en algunos topónimos citados puede ser doble: falta de cultura del copista que le tomaba su relación de viaje (que no conocería la grafía clásica acuñada por el uso de estos topónimos) y, en segundo lugar, puede verse también una influencia fonética: los nombres fueron tomados tal y como creyó oírlos un copista poco avezado. Ello explicaría las irregularidades gráficas del nombre España, Sierra Nevada (Ŷabal Sulayr), de Baza (Bașta), Almuñécar (Muna$\mathrm{kab})$.

Estos datos -lingüístico, cronológico (del uso de "España") y ortográfico- nos sitúan a su autor más en el Mágreb (o cercano a él) que en Al-

65. Al-Gassānī en el s. XVII, o Al-Gazzāl e Ibn "Uțān en el s. XVIII escribieron "Iṣbāniya" o "bilād Ișbāniya", apud. Nieves PARADELA AlONSO, El otro laberinto español. Viajeros árabes a España entre el s. XVII y 1936, Madrid, Ediciones de la Universidad Autónoma de Madrid, 1993, pp. 72-73.

66. Cfr. M. Jesús RubierA, Literatura hispanoárabe, Madrid, ed. Mapfre, 1992, 283 pp. 
Andalus, y más propiamente en los ss. XVI o siguientes que en un s. XV. Son, por ello, elementos de importancia a tener en cuenta para el estudio que aún está por hacer.

\section{DATOS ECONÓMICOS}

No vamos a reproducir aquí lo que dice de la economía de cada lugar, pues el texto es lo suficientemente explícito. Ahora bien, considerado desde un punto de vista puramente de historia económica, no aporta ningún dato nuevo que no conociéramos con anterioridad; puede decirse, incluso, que reproduce tópicos ya conocidos.

Como en todo escritor musulmán (y contemporáneo, ver si no las descripciones de J. Münzer), a una ciudad se la considera según la calidad de sus construcciones ("bellos edificios privados, buenas construcciones públicas y ríos surcándola por medio de ella", "edificios privados y alcázares", etc.) y la facilidad de sus abastecimientos alimentarios. Todo ello, reitera, que posee en abundancia Granada. La ausencia de necesidades es otro punto positivo: "No hay en ella nadie hambriento, ni desnudo, ni quien proteste, ni quien llore, y esto indica que reina la justicia y la benevolencia", así como la apariencia externa de sus gentes: "se ven elegantes brocados en hombres, niños y mujeres y son frecuentes los ricos trajes y los vestidos".

En segundo lugar, la abundancia de producción agrícola es la base económica fundamental para un enclave ("abundan las aguas, los sembrados, los cultivos, las huertas, las verduras", "no se interrumpe la producción de cosechas en el campo, ni de frutos, en el que sus cereales son abundantes", etc.); de Baza se resalta su azafrán, lo mismo que en Almuñécar la caña de azúcar. Si a ella unimos una ganadería pujante ("Hay extensos sembrados, mucho ganado, excelentes dehesas") y la existencia de artesanía y comercio, nos hallamos ante un panorama casi ideal. Esto es lo que nos transmite del Reino de Granada.

Curiosamente afirma que la única manufactura existente en el reino es la del tejido de la seda ("No se ve en el país otra manufactura; es todo lo que produce su población en cuanto a artesanías"), cuando sabemos de la hacendosidad artesana de los granadinos. La producción sedera ciertamente era muy rentable e importante para Granada, pero no era la única manufactura del reino ${ }^{67}$; él mismo resalta la producción de loza dorada de Málaga.

Finalmente, del comercio, únicamente resalta Almería como su sede primordial, a la par que no deja de citar el ambiente general de justicia, equilibrio en los cambios y buen sentido de los mercaderes granadinos, que hay que entender en clave de máxima alabanza (dado el cariz general de la pica-

67. Sobre la producción sedera granadina ver R. ARIÉ, op. cit., pp. 355-356. 
resca comercial y de los cambios monetarios): "hay rectitud en toda la administación de justicia: en el almotacenazgo, en los precios, en las ventas y en las compras, tomando precauciones contra la usura, y observando lo lícito".

\section{EL REINO DE GRANADA SEGÚN ALGUNOS RELATOS DE VISITANTES TARDÍOS}

\section{RELACIONES DE VIAJE DE OTROS VIAJEROS MUSULMANES ANTERIORES}

Contrastan vivamente estos seis fragmentos con los relatos más o menos largos y verosímiles de otros viajeros musulmanes. Hemos escogido como ejemplo tres viajeros anteriores en diversa medida a Ibn Aṣ-Ṣabbāh. Los tres vivieron en una sociedad islámica y conocemos sus obras por completo; en ellas recogieron una serie de relatos realistas, coherentes y descriptivos de la Granada o las gentes que conocieron. Cronológicamente, el primero de ellos es de un siglo anterior, pero los otros dos le preceden escasamente treinta años.

1. Aunque más de un siglo anterior, debe mencionarse a Ibn Batțūta (704-779/1304-1377) por ser su riḥla obra modelo del género. Sabemos que estuvo personalmente en un reino de Granada asediado por los cristianos, pero aún lejos de los agobios del siglo XV. El trotamundos tangerino le dedica cierta atención a su viaje y estancia en el Reino de Granada ${ }^{68}$. Allí estuvo en 1350, cuando acababa de morir por la peste Alfonso XI en el sitio de Gibraltar, y reinaba el sultán Yūsuf I (1333-1354).

Aunque Ibn Battuata hiciera un viaje corto en distancia, nos parece en exceso escueto su relato del mismo (más, si descontamos los excursos eruditos que introdujo Ibn Ŷzayy). Llega a Gibraltar; mención de su fortificación por Abū-l-Hasan y personajes que conoce allí; excurso literario de Ibn Ŷuzayy: origen del topónimo, reconquista de ésta por Abū-l-Hasan y treta por la que se perdió, fortificación y dos poemas de Ar-Rușāfī; vuelta al relato del viaje-

68. Šams Ad-Dīn Abū ${ }^{\mathrm{c}} \mathrm{Abd}$ Allāh Muhammad Ibn ${ }^{\mathrm{c}} \mathrm{Abd}$ Allāh Ibn Muhammad Ibn Ibrāhīm

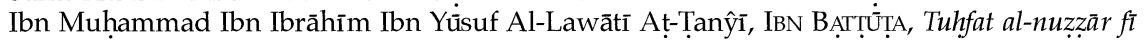

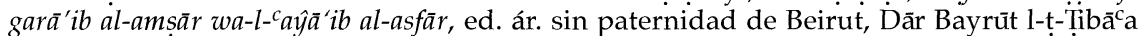
wa-n-Našr, 1970, 749 pp., parte sobre Al-Andalus en pp. 664-676, en la trad. esp., estudio de Serafín FANJul; Federico ARBó, Ibn Battututa. A través del Islam, Madrid, ed. Editora Nacional, 1981, está en las pp. 757-765; más datos en nota 49 de nuestro anterior estudio sobre $I b n$ Aș-Śabbāh. Esta atención que le dedica a Granada parece notable si vemos la traducción española (en la que se le ha reservado un capítulo aparte al Reino de Granada), pero se ve atenuada cuando, al ver la edición del texto árabe, comprobamos que el relato de su viaje a la Península Ibérica sigue, sin solución de continuidad, a diversas historias sobre el Mágreb y a un panegírico al sultán marroquí, y sólo incluye un epígrafe diferenciado titulado "Mención del sultán de Granada», cuyo final no está definido (pues dentro del citado epígrafe se inicia la narración sobre el Malí, también sin solución de continuidad). 
ro: viaje a Ronda y conocidos allí; Marbella; entrada cristiana desde el mar y derrota a una partida militar musulmana cerca de Málaga; las producciones de Málaga; dos poemas de malagueños incluidos por Ibn Ŷuzayy; Ibn Bațtutata menciona los personajes que le cobijaron y conoció en Málaga; descripción de ésta; sigue la marcha a Granada; poema sobre ésta de Ibn Yuzayy; "Mención sobre el sultán de Granada" y su aparato administrativo; poema y personalidades, por Ibn Ŷuzayy; personajes de lo más diverso mencionados por Ibn Bațuata; viaje de vuelta por Alhama, Ronda, etc., hasta Gibraltar.

Es un relato extraño, por breve, y porque según afirma Ibn Bațtūta el motivo inicial de acudir a Al-Andalus fue: en Ceuta "en la cual residi durante muchos meses, tres de ellos enfermo, pero Dios me sanó y quise tomar parte en el yihād y el ribăt ${ }^{\prime \prime 69}$, pero en cambio, al ver los resultados de una escaramuza militar en Málaga, parece que decide volver al Mágreb.

Casi seguro que la causa por la que el relato del periplo granadino sea tan breve haya que reprochársela a Ibn Ŷuzayy, autor de la versión final de la obra. Evidentemente, la descripción de Granada no permitía tanto lucimiento como la de otras regiones del mundo. Para un literato con el prurito de Ibn Ŷuzayy no es de extrañar que, ante la posibilidad de la menor crítica por parte de los cultos lectores magrebíes, optara por abreviar esta parte. Prefirió brillar con la descripción de otros lugares del mundo antes que con la de Granada, de sobra conocida para sus lectores. Ésta es la verdadera causa, y no la falsa modestia justificativa con que pueden entenderse las palabras del propio Ibn Ŷuzayy: "Si no temiera que me tildasen de parcial -por ser mi ciudadme extendería largamente describiendo Granada, puesto que la ocasión es propicia. No obstante, no tiene sentido prodigarse hablando de una ciudad tan renombra$d a^{\prime \prime 70}$.

2. Más detalles proporciona ${ }^{\mathrm{C}} \mathrm{Abd} \mathrm{Al}-\mathrm{Basīt}$ (m. después 869.70/1465.6), viajero de origen egipcio. Su periplo por el Reino de Granada entre el $15 \mathrm{rabi}^{\mathrm{c}}$ II-fin ŷumãdà $870 / 5$ diciembre de 1465-febrero de 1466 nos ha llegado por escrito, formando parte de su gran viaje por el Mágreb ${ }^{71}$. Sus impresiones son también de un gran interés, lo cual motivó a G. Levi della Vida a publicar este fragmento de su obra. De Granada hace un escueto y detallado informe (breve debido a una trágica y desconocida desgracia que le aconteció al autor $)^{72}$. El resumen de lo narrado es el siguiente: salida desde Orán en

69. IBN BAṬTuTṬ, op. cit., ed. ár. p. 664; trad. esp. p. 757.

70. IBN BAṬṬŨṬ, op. cit., ed. ár. p. 670; trad. esp. p. 763.

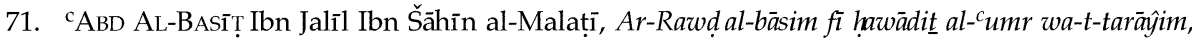
ed. ár. parcial y trad. ital. de dos fragmentos sobre el Reino de Granada: Giorgio LEVI DELLA VIDA, «Il regno di Granada nel 1465/66 nei ricordi di un viaggiatore egiziano», Al-Andalus, Madrid-Granada, ed. C.S.I.C., n. ${ }^{\circ}$ I, 1933, pp. 307-334.

72. Cfr. apuntes breves sobre el traje granadino, costumbres y tradiciones, así como ejército y armada granadinos en las obras de Ibn Batțūta, ${ }^{c} \mathrm{Abd}$ Al-Basīt, J. Münzer y otros viajeros europeos en Ahmad Muhammad AṬ-ṬUjī, «Garnāta al-islamiyya fī naḍar ar-raḥhāla al-aŷānib», Awrāq, n. ${ }^{\dot{4}}$, Madrid, ed. I.H.A.C., 1981 , pp. 141-145. 
nave genovesa con varios acompañantes; llegada a Málaga y personajes que conoce allí; anécdota con un desertor musulmán; ataque cristiano; fuente para el abastecimiento de agua a Málaga; vientos huracanados; camino hacia Vélez y descripción de ésta; Alhama y descripción de sus baños; llegada a Granada y comparación con Damasco y Siria; personajes conocidos; paseo por el Albaicín y descripción de su mezquita; descripción de la Alhambra; los ríos Darro y Genil; rememoración de otras ciudades andalusíes famosas, en manos de los cristianos; retorno a Orán. Hay que resaltar el gran cuidado y detalle que muestra con las fechas (relación diaria de hechos) y con los nombres de personas, circunstancias, fechas, etc., garantía de verosimilitud en todo lo relatado.

3. Al-Qalașādī (815-891/1412-3-1486) es el personaje más parecido a Ibn Aș-Ṣabbāh, cronológica y geográficamente ${ }^{73}$. Fue experto en las ciencias de la religión, especialmente en fiqh, originario y educado en Baza, posteriomente trasladó su residencia a la capital granadina. En el año 840/1436.7, con 25 años, emprende su "riḥla fĩțalab al-culūm", un "viaje de estudios" en que aprovecha su estancia para aprender en cada lugar con los sabios más reputados del mismo. Se traslada a Tremecén, a Túnez, que recorre durante dos años y medio. Por Trípoli y Alejandría llega a El Cairo, donde reside más de 13 meses antes de seguir hacia la Bekaa en el Líbano, hacer el "haŷy", y volver a Al-Andalus a los 15 años de haber salido. Se instala en Granada; finalmente se traslada a Bāŷa, en Túnez, donde morirá en 891/1486.

Cabría pensar que por haber residido en Granada debió conocerla bien, y que este conocimiento lo encontraremos en su obra, pero ésta es un largo listado de sabios que conoció o con los que estudió; es un currículum. Se inicia con su estancia y educación en Baza, siendo esto todo lo que hay del Reino de Granada ${ }^{74}$ : concretamente, enuncia 6 personajes con los que aprendiera $^{75}$, para finalizar esta parte primera de su obra con una breve descripción de Baza, y dos poesías elogiosas sobre ella.

4. Si recapitulamos, vemos que del relato de Ibn Battūta se pueden extraer datos sobre Gibraltar, Málaga y Almuñécar y un lamento por la pérdida

73. Abūl-Hasan 'Alī Al-QALASĀAī Al-Andalusĩ, Rihla, ed. ár., est., notas: Muhammad ABŪL-

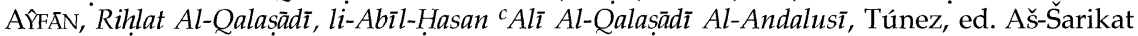
At-Tūnisĩya li-t-Tawzīac, 1399/1978, 254 pp. Trad. fr. y estudio de su breve prefacio (basándose en el manuscrito tunecino): Mohamed SOUISSI, «En parcourant les préfaces des ouvrages scientifiques en langue arabe», Les Cahiers de Tunisie, Túnez, ed. Faculté des Lettres et des Sciences Humaines de Tunis, n. ${ }^{\circ} 85-86,1974$, pp. 147-162; trad. fr. del fragmento tunecino de su rihla: Jomaa SASSI, «Le periple de Qalasādī en Tunisie», IBLA, t. 57, n. ${ }^{\circ} 174$, Túnez, ed. Institut des Belles Lettres Arabes, 1974, pp. 295-302.

74. Al-Qalașādì: Rihla, pp. 81-94.

75. Son los sabios que conociera en Baza: ' Alī Ibn ' ${ }^{\mathrm{C}} \mathrm{Azīz} ;$ Muhammad Al-Qastrilī; Abū Bakr Al-

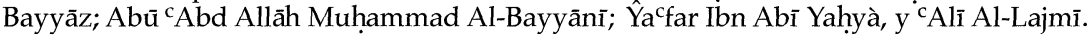


de Al-Andalus. La obra de Al-Qalașādĩ describe Baza y nos da los nombres de seis preclaros sabios bastetanos. De esta tríada de viajeros que conocen el epígono del Reino de Granada es ${ }^{\mathrm{c}} \mathrm{Abd}$ Al-Basīt, el sabio egipcio, el que viene de más lejos, quien más detalles nos aporta en su obra; este "turista" es el único que incluye los datos que esperaríamos de cualquier viajero que pase por Granada: personajes famosos, descripciones del Albaycín y su mezquita, de la Alhambra, de la metrópoli granadina, de sus ríos..., así como de los lugares por los que pasa en su llegada, y a su vuelta.

Aparte de ello, Ibn Batțūta y ${ }^{\mathrm{C}} \mathrm{Abd}$ al-Basīt nos dejan traslucir la angustia que a los musulmanes producían los ataques cristianos: tanto el tangerino, como el egipcio, habituados a viajar de modo más o menos seguro por el mundo islámico, encuentran que en Al-Andalus esa inseguridad que siempre se agazapa en cada ribazo de cualquier camino se tornaba peligro real y tangible. El propio Ibn Battutata nos lo cuenta de tal modo que podemos sentir su propio desasosiego, mientras que el turista egipcio también refiere otro ataque cristiano. Fuera de la descripción de la Granada del s. IX/XV de ${ }^{\mathrm{c}} \mathrm{Abd}$ Al-Basít, los elementos más notables a resaltar quizás sean: este elemento de vivencia personal, de riesgo cercano, tangible y, parejo, el sentimiento religioso generado por un agresor infiel ante el que se sienten impotentes los musulmanes. Éste será el elemento religioso y de (super)vivencia que, sublimado y casi protagonista, encontramos en las alusiones al Reino de Granada de Ibn Aṣ-Ṣabbāḥ.

\section{El Reino de Granada SEGÚn la obra de Al-HaŷArĩ}

El género literario árabe de la "riḥla", con una personalidad y evolución propias, también ofrece algunos ejemplos en las épocas mudéjar y morisca ${ }^{76}$. De estas obras, solamente hallamos noticias sobre el Reino de Granada en el Nāṣir Ad-Dìn ${ }^{c}$ alà l-qawm al-kāfirīn de Aḥmad Ibn Qāsim Ibn Aš-Šayj Al-Haŷārī Al-Andalusī (970-1055/1570-1645) ${ }^{77}$. Se encontraba en Granada sobre 1597 y

76. Remitimos al epígrafe que le dedicamos al tema en el anterior estudio sobre Ibn Aṣ-Ṣabbāḥ, pp. 387-389.

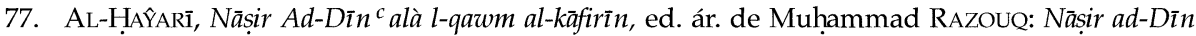
calà l-qawm al-käfirinn. Mujtașar rihlat aš-šihāb ilà liqã' al-aḥāa li-Ahmad Ibn Hāsim Al-Hâyarĩ Al-Andalusī (Afüqāyy), Dār Ail-Baydạa', ed. Manšūrāt Kulīyat Al-Ādāb wa-l-'Ủlūm Al-Insãnīya, 1987/1407, 167 pp. Parte sobre Al-Andalus trad. ital. de Clelia SARnelli CerQuA, "Al-Hağarī in Andalusia», Studi Magrebini, Nápoles, vol. III, 1970, pp. 161-203, ver también id., «La contribution d'Al-Hağarī a l'histoire d'Al-Andalus», Revista del Instituto Egipcio de Estudios Islámicos en Madrid, n. ${ }^{\circ} 23$, Madrid, 1985-1986, pp. 113-119. Ver nota 51 de nuestro anterior estudio sobre Ibn As-Ṣabbāh y añadir: M. HAJJI, «Le voyage en Hollande d'Afuqay au début XVIIe. siècle», Le Maroc et la Hollande. Actes de la Deuxième Rencontre Universitaire. Etudes sur l'histoire, la migration, la langue et la culture, Rabat, 1990, pp. 29-33; Gerard WIEGERS, «A life between Europe and the Maghrib. The writings and travels of Ahmad ibn Qāsim ibn al-faqīh Qāsim ibn al-shaykh al-Hajarī al-Andalusī (born c. 977/1569-70)", Orientations. The Middle East \& Europe: Encounters \& Exchanges, Leiden, 1993, pp. 87-115. 
fue invitado por el arzobispo a traducir los "libros plúmbeos"78, recientemente aparecidos; de este modo obtuvo autorización para actuar como intérprete del árabe al castellano y viceversa. En su obra, le dedica el capítulo en que pasa por España a contar estas peripecias granadinas relacionadas con el desciframiento de los plúmbeos. La Granada que nos muestra es ya bien lejana, de la apenas entrevista a través de la obra de Ibn Aṣ-Ṣabbāḥ.

\section{LA GRANADA DE JERÓNIMO MÜNZER}

Finalmente, en un grupo diferente consideraremos al viajero alemán Jerónimo Münzer (1460-1508), quien podría decirse contemporáneo de Ibn Aṣ-Ṣabbāḥ. En su Itinerarium Hispanicum ${ }^{79}$, dejó escritas sus impresiones y unas valiosas notas sobre la Península Ibérica que recorriera durante casi cinco meses (17 septiembre 1494-9 febrero 1495). Está en el Reino de Granada entre 20-29 de octubre de 1494 y deja una larga y minuciosa relación de sus observaciones, vivencias y del agasajo que le hiciera el conde de Tendilla.

Resumimos escuetamente los epígrafes. Granada: descripción de la ciudad y su mezquita; descripción de la Alhambra, sus partes y detalles: heráldica, jardines, torres; cementerio de puerta Elvira; el Albaicín: su mezquita, peculiaridades, oración; larga descripción geográfica y económica de la ciudad de Granada y de su vega; sus casas, urbanismo musulmán y cambios cristianos en éste; notas de geografía y economía del Reino de Granada, mención de sus ciudades; reseña de la conquista del reino por Fernando de Castilla; toma de la Alhambra y liberación de cautivos cristianos; origen nobiliario de la guerra contra Granada; oro en el río, al pie de la Alhambra; "ritos y vestimentas de los sarracenos": notas sobre el Islam, oraciones, ayuno, vestidos; juegos de los militares castellanos en la Alhambra; personalidad del arzobispo Hernando de Talavera; iglesias y monasterios de la ciudad, sus rentas; el castillo de Moclín, descripción y conquista; Alhama; Vélez-Málaga.

Evidentemente en Münzer concurren una serie de circunstancias diferenciales: se trata de un alemán, cristiano europeo, culto y tolerante, pero cuya formación le hacen ver esta Granada, no como la ciudad islámica en pe-

78. Cfr. Miguel José HagerTy, Los Libros Plúmbeos del Sacromonte, Madrid, Editora Nacional, 1980, 317 pp. + ils. Sobre el entorno religioso-cultural que propició su aparición: Míkel de EPALZA, «Le milieu hispano-moresque de l'Evangile islamisant de Barnabé (XVIème.XVIIème. siècle)», Islamochristiana, Roma, ed. P.I.S.A.I., 1982 y Luis Fernando BERNABÉ PONS, El evangelio de San Bernabé: Un evangelio islámico español, Alicante, ed. Universidad de Alicante, 1995, $260 \mathrm{pp}$.

79. Hemos consultado la trad. esp.: Jerónimo MÜNZER, Viaje por España y Portugal (1494-1495). Nota introductoria de Ramón Alba, Madrid, Ediciones Polifemo, 1991, pp. 89-141. Cfr. Bernard VINCENT, «La vision du Royaume de Grenada par les voyageurs étrangèrs au tournant des XVè. et XVIè. siècles», Chronica Nova. Revista de Historia Moderna de la Universidad de Granada, n. ${ }^{\circ}$ 15, Granada, ed. Universidad de Granada, 1986-1987, pp. 301-312. 
ligro, o como parte del Islam (caso de los viajeros antedichos), sino desde la perspectiva de la "alteridad", del viajero a quien llama poderosamente la atención todo lo hispánico, cuanto más una Granada mudéjar recién anexionada a Castilla. Nuevamente hemos de destacar el cuidado que pone en la narración de los detalles, así como en recoger historias y descripciones "exóticas" que serán del agrado de sus hipotéticos lectores europeos, y cómo consigna su periplo granadino día a día.

\section{SEGUNDO COLOFÓN PROVISIONAL}

El Reino de Granada que entrevemos a través de estas líneas es un territorio difuso, rico, piadoso y difícil. Como se ha visto, de la comparación de otros textos similares de relatos de viajeros musulmanes o de J. Münzer, el afán de Ibn Aș-Ṣabbāh no es descriptivo, no busca ser testigo de su época, o de lo que percibió en sus viajes. Más bien, al contrario, su mirada es retrospectiva y piadosa, más parecida a la mirada de otros viajeros posteriores, o incluso a la Rihlat Al-Andalus de $\mathrm{H}$. Mu'nis ${ }^{80}$ que a las detalladas narraciones de viaje de otros viajeros más o menos coetáneos, como los citados.

Pero hay que resaltar el sospechoso parecido temático de estos fragmentos con las alabanzas que dedica al Reino de Granada Lisān Ad-Dīn Ibn Al-Jatiib (713-776/1313-1375) en algunas de sus obras. Así, determinadas frases elogiosas de la rihla de Ibn Aṣ-Ṣabbāh parecen resumidas de su Jațat attayf $f^{81}$, y las descripciones de las ciudades del Reino de Granada reenvían a las más extensas del Mič yār al-ijtiyār ${ }^{82}$.

De este modo, podrían apuntarse dos hipótesis interpretativas sobre la personalidad y obra de Ibn Aṣ-Ṣabbāḥ Ŷ. Šaija le considera como el último rahhạl clásico (añadiríamos que quizás el primero que aporta una visión ya sublimada, no comparable a la culta del citado $\mathrm{H}$. Mu'nis, sino puramente religiosa). En este sentido hemos de recordar que es un mudéjar, un personaje musulmán viviendo en una sociedad cristiana. Bajo este prisma han de considerarse las, quizás, más relevantes aportaciones de estos textos: las alusio-

80. Hụssayn Mu’NIs, Rihlat Al-Andalus: Hadīt Al-Firdaws al-maw'ūü, El Cairo, ed. Aš-Šarikat Al-c'Arabiya li-t-Tibāc ${ }^{\circ}$ wa-n-Našr, 1983, 443 pp. Cfr. Hany Muhammad EL-ERYAN, «"Viaje por Al-Andalus" de Hussain Mu'nis», Revista del Instituto Egipcio de Estudios Islámicos en Madrid, Madrid, ed. Instituto Egipcio de Estudios Islámicos / I.C.M.A., vol. XXVI, 1993-1994, pp. 161-167.

81. IBN AL-JAṬīB, Jatrat at-tayf wa-rihlat aš-šițā' wa-ṣ-ṣayf, editada dentro de la obra de Ahmad

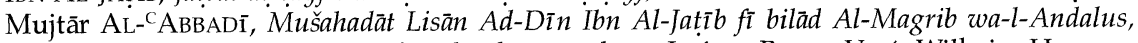
Alejandría, 1958, pp. 25-53. Traducida al español por Jacinto BOSCH VILA; Wilheim HoENER$\mathrm{BACH}$, «Un viaje oficial de la corte granadina (año 1347)», Andalucía Islámica. Textos y Estudios, n. 2-3, Granada, ed. Universidad de Granada, 1981-1982, pp. 33-69.

82. IBN AL-JATĪB, Micyār al-ijtiyār fī dikr al-maca āhid wa-d-diyār, obra editada y traducida por Muhamad Kamäl ŠABBĀNA, Rabat, ed. Instituto Universitario para la Investigación Científica de Marruecos, 1977/1397, 164 pp. 
nes a los mudéjares que se han quedado en Al-Andalus. Su fin sería inmediato y modesto: la mentalización de los correligionarios mudéjares almerienses, y su instrucción. En este caso, la baja calidad del texto y las generalidades narradas no servirían si no es en función de la esperanza religiosa que transmite el texto. Es en esta clave piadosa, por un lado, y autojustificativa para los mudéjares que se quedaron en $\mathrm{Al}$-Andalus en la que creemos deben entenderse sus palabras.

Pero los breves y genéricos apuntes que da sobre un Reino de Granada que era su tierra de origen y debería conocer bien, la extraña narración de su estancia en Santa Sofía de Constantinopla, así como su estilo, nos hacen preguntarnos si no se trata de un autor posterior, quizás de época moderna, que se basa en fuentes anteriores para componer una obra literaria de creación, estructurada como rihla. En este sentido, conocedor seguro de las obras de Ibn Al-Jatīb, es posible que tomara de alguna de ellas estos temas elogiosos (bastante comunes y generales, por otro lado). En detrimento de esta hipótesis interpretativa está el pedestre lenguaje que utiliza el autor, que sería mal trasunto de Ibn Al-Jatiib.

Como se ve, el análisis fragmentario de una obra sólo puede producir conclusiones parciales y provisionales. De momento la primera de las dos hipótesis apuntadas parece ser la más lógica, aunque las incoherencias y elementos ilógicos que presentan los fragmentos analizados en nuestro anterior estudio y en éste pueden convencer de la segunda apuntada.

\section{RESUMEN}

Tras el estudio dedicado en el número anterior a la figura del mudéjar almeriense del s. XV Ibn Aṣ-Ṣabbāḥ y a su obra Minšăb al-ajbār wa-tadkirat alajyär, se traducen seis fragmentos que incluye esta obra referentes al Reino de Granada y se estudian los datos que aporta: lingüísticos, cronológicos, toponímicos y económicos. Se compara esta visión del reino granadino con las aportadas por otros viajeros árabes tardíos, y por Al-Ḥaŷārī y J. Münzer.

\section{ABSTRACT}

After the study on the figure of the Mudejar of the 15th century Ibn Aṣ-Ṣabbāh from Almería, and on his work Minšăb al-ajbār wa-tad in the previous number, now six fragments referring to the Kingdom of Grenada, which are included in this book are translated, and the linguistic, chronological, placenames and economic data that provides are studied. This vision of the Kingdom of Grenada is compared to the one provided by other late Arabic travellers, Al-Hayâāī and J. Münzer. 


\section{SHARQ AL-ANDALUS Estudios Mudéjares y Moriscos}

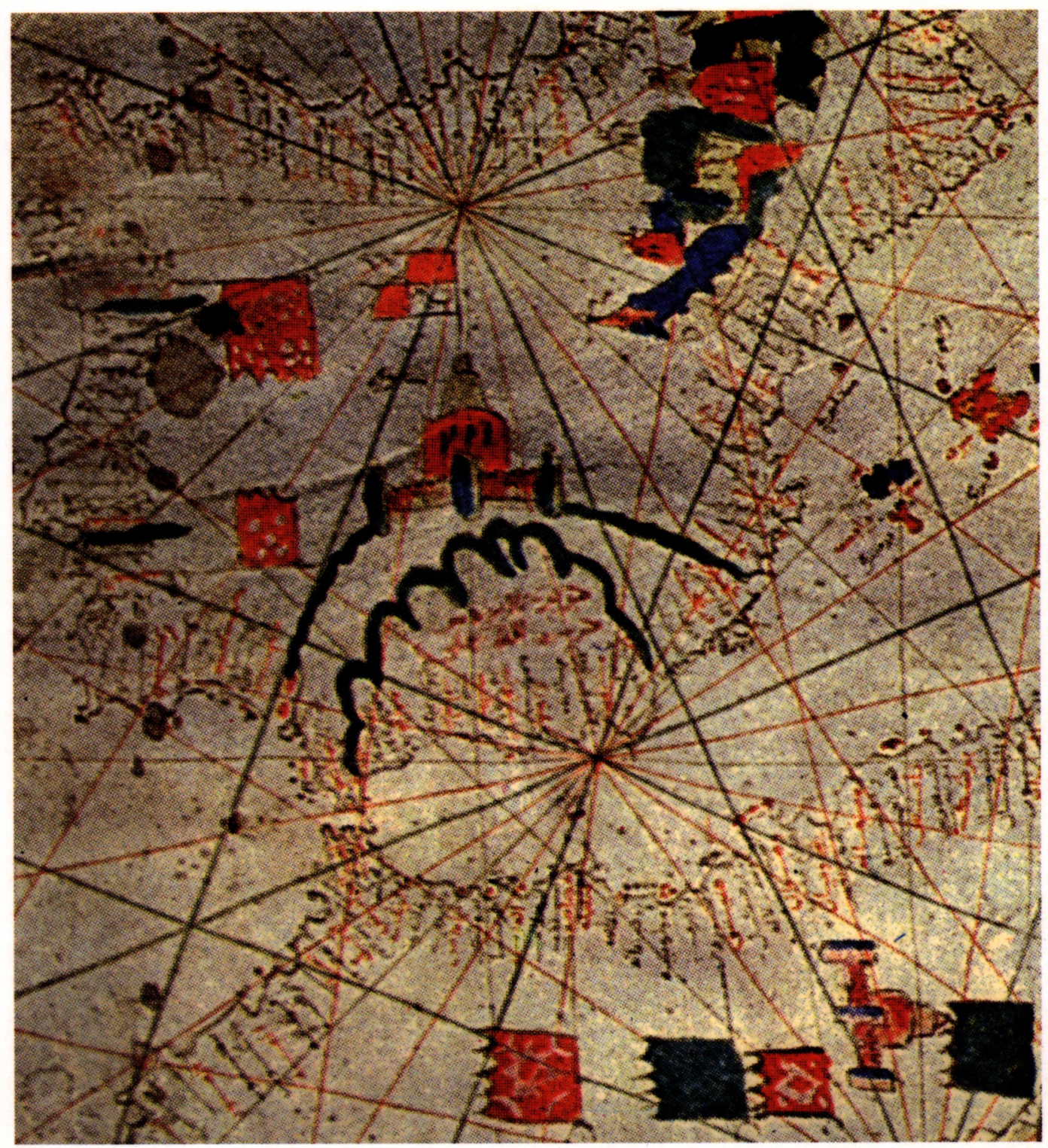

Núm. 13, Teruel-Alicante, 1996

Centro de Estudios Mudéjares - Instituto de Estudios Turolenses Área de Estudios Árabes e Islámicos de la Universidad de Alicante 
SHARQ AL-ANDALUS

Estudios Mudéjares y Moriscos

\author{
Director \\ María Jesús Rubiera Mata \\ Co-Director \\ Esteban Sarasa \\ Secretario de redacción \\ Luis F. Bernabé Pons \\ Co-Secretario \\ Antonio Gargallo Moya ( $†$ ) \\ Coordinador \\ Francisco Javier Sáenz Guallar \\ Comité de redacción \\ Gonzalo Borrás Gualis \\ Míkel de Epalza \\ Francisco Franco Sánchez \\ Bernard Vincent \\ Jesús Zanón Bayón
}

\title{
Comité Asesor
}

Comité Científico del Centro de Estudios Mudéjares, con exclusión de las personas mencionadas anteriormente

\section{Portada}

Fragmento peninsular del portulano árabe de Ibrahim de Murcia, Trípoli, 1463

$$
\begin{gathered}
\text { Depósito Legal } \\
\text { Z-2.924-96 }
\end{gathered}
$$

Impresión

INO Reproducciones, S. A.

Ctra. de Castellón, km 3,800, Pol. Miguel Servet, nave 13, 50013 Zaragoza

\section{Editores}

CENTRO DE ESTUDIOS MUDÉJARES - INSTITUTO DE ESTUDIOS TUROLENSES

ÁREA DE ESTUDIOS ÁRABES E ISLÁMICOS DEL DEPARTAMENTO

DE FILOLOGÍAS INTEGRADAS - UNIVERSIDAD DE ALICANTE

El Centro de Estudios Mudéjares es una institución adscrita al Instituto de Estudios Turolenses y patrocinada por el Gobierno de Aragón,

la Excma. Diputación Provincial de Teruel, el Excmo. Ayuntamiento de Teruel y la Caja de Ahorros de la Inmaculada

\section{Difusión}

\section{CENTRO DE ESTUDIOS MUDÉJARES}

(Instituto de Estudios Turolenses, Apdo. de Correos 77, 44080 Teruel) 